\title{
Microorganism Distribution that Causes Abortionin Females of Fallujah City
}

\author{
Asif Hasan Abdulrazaq ${ }^{1}$, Leqaa Majeed Aziz ${ }^{2}$, Mohammed Jobair Muhaidi ${ }^{1}$, Ahmed Naji Lateef \\ ${ }^{1}$ Assist. Prof. Dr. College of Applied Science, ${ }^{2}$ Assist. Prof. Dr. College of vet.medicin, \\ University of Fallujah, ${ }^{3}$ Researcher, Ministry of Health, Fallujah Hospital, Iraq
}

\begin{abstract}
The research included the study of microbiological content in the reproductive system and urinary tract infections for abortions cases in the city of Fallujah. For this purpose, 121 swabs were taken, including 50 swabs of the genital system (27 Vaginal and 23 Endo cervical swabs) and 71 swabs of urine. The result refer to that only 27 samples gave negative bacterial growth, while the other 94 samples showed growth of more than one species of bacteria on different media. The bacterial population isolated from the urine was highest $(81.7 \%)$, followed by vagina $(74.1 \%)$ and the endo cervical $(69.6 \% \%)$. The results showed that the ratios of the isolated bacterial samples were Escherichia coli (54.4\%), Streptococcus agalactiae (17\%), Staphylococcus aureus (12\%), Klebsiella (8.5\%), Pseudomonas aeruginosa (5.3\%), Proteus (1\%) and Candida albicans (1\%). The E. coliwas the most common type bacterial isolates.Antibiotic sensitivity tests against 24 antibiotics were reveal that bacteria Escherichia colihave multiple resist against different antibiotics, most isolates were highly resistant to Aztroenam followed by cefotaxime and ciproflaxime respectively, while their resistance to other antibiotics varied.The results also showed that Proteus which isolated from urine samples and Candida albicans which isolated from vaginal specimens were the lowest percentage, where only one isolate was obtain for each and the Candida abicans were resistant to all of different antibiotics used in this study.
\end{abstract}

Keywords: Females; abortion; Microorganism; Health

\section{Introduction}

Women who infected with bacteria during pregnancy period to risk of miscarriage or childbirth before the pregnancy is complete ${ }^{(1)}$, most of these cases caused by bacterial genital tract infection ${ }^{(2)}$.

The genital tract, especially the vagina, may be infected with virulance microorganisms, such as Gardnerella vaginalis, group B streptococci, Staphylococcus aureus, Ureaplasma urealyticumor Mycoplasma hominis, which can displace Lactobacilli

\author{
Corresponding Author: \\ Asif Hasan Abdulrazaq \\ Assist. Prof. Dr. College of Applied Science, University \\ of Fallujah, Iraq \\ e-mail: drmustafasalah7@gmail.com
}

that can change vaginal $\mathrm{pH}$ from 3.8 to $7^{(3,4)}$. Bacteria of genital tract are found in $40 \%-50 \%$ of women of reproductive age which causing bacterial vaginosis ${ }^{(5,6)}$, which diagnosed by using microscopy examination of vaginal swab samples and treated with appropriate antibiotics such as metronidazole ${ }^{(7)}$. Also, infection of the bacterial genital tract during pregnancy periods is not only risk to the mother but also to the neonate for example the infection with Streptococcus agalactiae can cause severe pneumonia, meningitis in neonates which often causes neonatal sepsis ${ }^{(8)}$ and a study showed that Streptococcus agalactiae premature rupture of membranes, leading to miscarriage or premature birth and a series of adverse pregnancy effects ${ }^{(9)}$. So Bacterial vaginosis has been closely related to abortion and premature birth $^{(10,11,12)}$. Also $E$.coli, which main causes of urinary tract infections, is one of an important factors in abortions and premature births ${ }^{(13)}$. 
A recent study recommended further research to clarify whether bacterial infections increase the risk of miscarriage and whether early diagnosis and treatment could improve reproductive outcomes ${ }^{(14)}$ of miscarriage in women of Fallujah city.

\section{Materials and Method}

Collection Samples: These study was conducted at in Fallujah city,Samples were collected monthly from January 2019 to April 2019. Women who were booked at gynecologists in antenatal clinics, during the study period were randomly selected, after that the Pregnant women receiving antibiotic treatment within 72 hours of days were excluded because of the fact that antibiotics should prevent or destroy pathogens,

Sampling Technique: One hundred (121) pregnant woman during the research period that either had any of the symptoms suggestive of urinary tract infections or without any symptoms were recruited into the study upon informed consent. Sample were divided in to three section:

1. urine culture examination (71) sample: Urine collection by sterile universal containers was given to the pregnant woman and midstream to avoid contamination, urine specimens collected and carried immediately to the microbiology unit for sample cultured and Microscopy.

2. High vaginal swab (27) sample.

3. Endocervical swab (23) sample.

Culture Technique: All the samples were inoculated
Into Brain - Heart Infusion broth was incubated at 24 hours, $37 \mathrm{C}$, after that from the growth inoculated Blood agar, Mannitol salt agar and MacConkey agar by using calibrated loop technique ${ }^{(15)}$. by streaked way may be obtained the appropriate way to the single-cell colony, The plates were incubated for 24 hours at $370 \mathrm{C}^{(15)}$

Identification of Bacterial Isolates: Complete identification of each bacterial isolates was based on a cultural examination, morphological examination, and biochemical characterization

Antibiotic Resistant: Antimicrobial susceptibility was performed by modified Kirby Bauer

Disk Diffusion technique ${ }^{(16)}$, used multiantibiotic disc to the detection all strain that isolated and know ability effect on strain by sensitivity or resistant for antibiotic.

\section{Results and Discussion}

the study conducted on randomly pregnant women sample in Fallujah city, From a total of 121 sample included urine, Vagina swabs, and endocervical swabs there were only 27 samples gave negative bacterial growth, while the number of bacterial growth were 94 isolates, showed more than one bacterial species on different culture media.

Prevalence rate of urine isolates were $81.7 \%$ while the vaginal isolates were $74.1 \%$ and endo cervical isolates were $69.6 \%$ from a total of positive specimens. Table (1).

Table (1): Distribution of different swabs which gave negative and positive results for bacterial inoculation on different media.

\begin{tabular}{|l|c|c|c|c|}
\hline Patients & Total No. of specimens & Positive specimens & Negative specimens & $\begin{array}{c}\text { Prevalence of Positive } \\
\text { Specimens }\end{array}$ \\
\hline Urine swabs & 71 & 58 & 13 & $81.7 \%$ \\
\hline Vaginal swabs & 27 & 20 & 7 & $74.1 \%$ \\
\hline Endo cervical swabs & 23 & 16 & 7 & $69.6 \%$ \\
\hline Total & 121 & 94 & 27 & \\
\hline
\end{tabular}

The results revealed there were six genera of bacteria were identified in addition to one species of yeast, which include Escherichia coli 54.4\%, Streptococcus agalactiae 17\%, Staphylococcus aureus $12.8 \%$,
Klebsiella 8.5\%, Pseudomonas aeruginosa 5.3\%, Proteus 1\%, and Candida albicas 1\% respectively. Table (2). 
Table (2): Bacterial species which isolated from urine, vaginal and endo cervical swabs and its Percentage

\begin{tabular}{|l|c|c|c|c|c|c|c|c|}
\hline \multirow{2}{*}{ Bacterial Species } & \multicolumn{2}{|c|}{ Urine } & \multicolumn{2}{c|}{ Vaginal } & \multicolumn{2}{c|}{ Endo cervical } & \multicolumn{2}{c|}{ Total } \\
\cline { 2 - 9 } & No. & $\begin{array}{c}\text { Percentage } \\
(\mathbf{\%})\end{array}$ & No. & $\begin{array}{c}\text { Percentage } \\
\mathbf{( \% )}\end{array}$ & No. & $\begin{array}{c}\text { Percentage } \\
(\mathbf{\%})\end{array}$ & No. & $\begin{array}{c}\text { Percentage } \\
(\%)\end{array}$ \\
\hline Staphylococcus aureus & 6 & $10.4 \%$ & 6 & $30 \%$ & 0 & $0 \%$ & 12 & $12.8 \%$ \\
\hline Streptococcus agalactiae & 6 & $10.4 \%$ & 4 & $20 \%$ & 6 & $37.5 \%$ & 16 & $17 \%$ \\
\hline Escherichia coli & 40 & $69 \%$ & 6 & $30 \%$ & 5 & $31.3 \% \%$ & 51 & $54.4 \%$ \\
\hline Proteus & 1 & $1.7 \%$ & 0 & $0 \%$ & 0 & $0 \%$ & 1 & $1 \%$ \\
\hline Klebsiella & 3 & $5.1 \%$ & 2 & $10 \%$ & 3 & $18.7 \%$ & 8 & $8.5 \%$ \\
\hline Pseudomonas aeruginosa & 2 & $3.4 \%$ & 1 & $5 \%$ & 2 & $12.5 \%$ & 5 & $5.3 \%$ \\
\hline Candida albicas & 0 & $0 \%$ & 1 & $5 \%$ & 0 & $0 \%$ & 1 & $1 \%$ \\
\hline Total & 58 & $100 \%$ & 20 & $100 \%$ & 16 & $100 \%$ & 94 & $100 \%$ \\
\hline
\end{tabular}

The causes of miscarriage in many cases are unknown. However, approximately $50 \%$ of early miscarriages showed abnormal chromosomal aberrations in the aborted fetus as changes in the structures or number of chromosomes ${ }^{(17)}$. Studies have shown that $78 \%$ of 101 histopathological samples of miscarriages were infected with bacterial (chorioamnionitis) compared with control samples which were uninfected ${ }^{(18)}$.

Our results agree with the findings of ${ }^{(19)}$ which found that the staphylococcus was predominant in urogenital diseases of pregnant women with threatened abortion also Streptococcus agalactiae was isolated in $11.8 \%$, While it was contrary to what was obtained from isolates of E. coli, where $69 \%$ was obtained in the urine while the researcher got $19 \%{ }^{(20)}$.

Researcher $^{(21)}$ found that induced abortion associated with group B Streptococcus (known as Streptococcus agalactiae) colonization. So the presence of these species in the genital tract could be one of the causes of abortion and suggesting that colonization of Streptococcusagalactiae in the genitourinary tracts may could be the risk factor for early-onset diseases ${ }^{(22)}$, and the colonization of these species in pregnant women is also an important cause of premature rupture of membranes, advanced miscarriage, premature birth and a series of disadvantage pregnancy outcomes ${ }^{(23)}$

Also the researcher ${ }^{(24)}$ founded that bacterial vaginosis not only related with abortion (spontaneous or induced), but also are associated with an increased risk of infertility.

The researcher found the urogenital infections are the most important health problems affecting (in) pregnancy women causing (of) cystitis, miscarriage, infertility and possibly death ${ }^{(25)}$.

The vaginal flora play essential role for reduction of $\mathrm{pH}$ resultant acid provided protection against infection but an overgrowth of bacteria especially in vagina reduction or cause absence of vaginal flora (26) which often associated with late miscarriages ${ }^{(27)}$. Also the (28) confirmed the role of the bacterial vagina (BV) as a predictor of miscarriage after 13 weeks' gestation.

And our results were agreement with ${ }^{(29)}$, who found that the mostly bacterial species were Escherichia coli which account to $80 \%$ to $85 \%$ the infection of UTI followed by Staphylococcus species that constitutes to $10 \%$ to $15 \%$. of the infection. In addition to bacterial species Klebsiella, Pseudomonas, Proteus species which plays a minor role in the infection. Therefore, the untreated infection of UTI during pregnancy may lead to premature labor or result in miscarriages which causes to infant's death.

The ${ }^{(30)}$ isolated many species of bacteria inculded: Chlamydia trachomatis, Enterococcus, Escherichia coli, Gardnerella vaginalis, Klebsiella pneumoniae, Mycoplasma hominis, Neisseria gonorrhoeae, Staphylococcus, and Streptococcus from patients assessed for chronic endometritis. And the prevalence of chronic endometritis in infertile patients estimated to $2.8 \%-39 \%$ and as high as $60 \%$ diagnosed with unexplained abortion $^{(31)}$.

The vaginal pathogens could passage to the cervix, through dilatation of the cervix and the loss of the cervical mucus plug during the miscarriage resulting in the infection of the endometrium and increased vascular 
permeability due to bacterial infections of endometrium allow the passage of the pathogen into the systemic circulation which causes of septic shock syndrome and the Klebsellia play important role in that case ${ }^{(32)}$ and the researcher ${ }^{(33)}$ found there were association between Escherichia coli and miscarriage in a study conducted on some cases in Nigeria

With regard to Candida albicans infections during pregnancy which association of chorioamnionitis, the researcher ${ }^{(34)}$ found that it can lead to late abortion.
The results of antibiotics sensitivity tests against 24 antibiotics showed there were multi resist for Candida albicans which isolated from vagina where was resist in $100 \%$ ratio to all antibiotics used in this study, followed by Proteus, which resisted 8 antibiotics in percentage $100 \%$ included cefipime, cefotaxime, doxycycline, aztroenam, nalidixic acid, imipenem, norfloxacin and levofloxacin. Whereas the Pseudomonas aeruginosa was resist to aztroenam, nalidixic acid and norfloxacin in $100 \%$ and resisted in $83.3 \%$ against cefotaxime, ciproflaxine, ceftriaxone and nitrofurantoin, while was less resistance against the other antibiotics where the resistance ranged from $66.7 \%$ to $0 \%$.Figure (1).

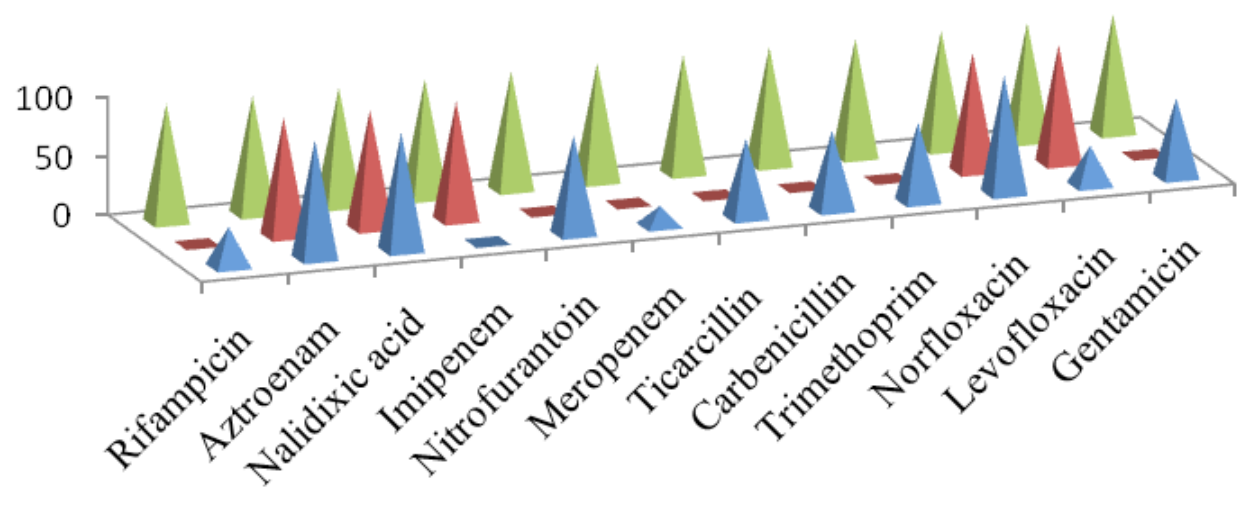

Figure (1): Antimicrobial susceptibility of Pseudomonas aeruginosa, Protus and Candida albicas.

The E.coli resisted against cefotaxime, ceftriaxone and aztroenam in $92.5 \%, 85.8 \%$ and $85 \%$ respectively while it was low resist to the other antibiotics ranged between $69.5 \%$ and $2.5 \%$.Klebsiellaisolates were resisted against aztroenam in $100 \%$ and against gentamicin in $89 \%$ but moresusceptibility to the others.

The obtained results that Klebsiella, Streptococcus agalactiae, Escherichia coli and Staphylococcus aureus showed highly resist against Aztroenam of in percentage
$(100 \%, \quad 88.7 \%, \quad 85 \%$ and $83.5 \%)$ respectively. The determination of resistance demonstrated that Escherichia coli had been resisted ciproflaxine in $92.5 \%$ and ceftriaxone in $85.8 \%$ while Staphylococcus aureus was resistance to the Nalidixic acid in $100 \%$. and the results apparent that resistance rates in all bacterial species varied between moderate resistance and sensitive against other antibiotics which used in this study. Figure (2). 


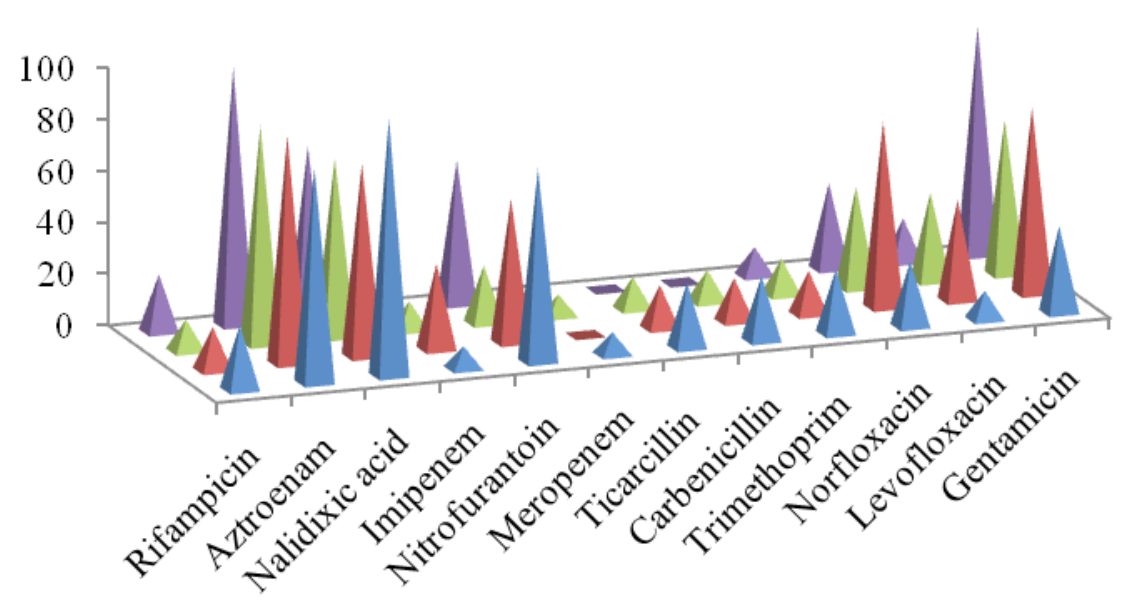

Figure (2): Antimicrobial susceptibility of Staphylococcus aureus, Streptococcus agalactiae, Escherichia coli and Klebsiella

These results disagree to findings of ${ }^{(36)}$ who found that bacterial vaginosis isolates were high level of sensitivity to Norfloxacin (75.6\%), ciprofloxacin $(79.6$ $\%)$ and gentamicin $(77.6 \%)$ whereas our results were opposite these results most of the bacterial isolates were resistance to the Norfloxacin (25\%-100\%) and but agree with resistance of gentamicin which were $(33.5 \%$ $100 \%$ ) except the Proteus was sensitivity.

Ethical Clearance: The Research Ethical Committee at scientific research by ethical approval of both environmental and health and higher education and scientific research ministries in Iraq

Conflict of Interest: The authors declare that they have no conflict of interest.

Funding: Self-funding

\section{References}

1. Summers PR. Microbiology relevant to recurrent miscarriage. Clin Obstet Gynecol 1994;37:722729.

2. Soper DE, Mayhall CG, Dalton HP. Risk factors for intraamniotic infection: a prospective epidemiologic study. Am J Obstet Gynecol 1989;161:562-568.

3. Casari E, Ferrario A, Morenghi E, Montanelli A. Gardnerella, Trichomonas vaginalis, Candida, Chlamydia trachomatis, Mycoplasma hominis and
Ureaplasma urealyticum in the genital discharge of symptomatic fertile and asymptomatic infertile women. New Microbiol 2010;33:69-76.

4. Wilson JD, Ralph SG, Rutherford AJ. Rates of bacterial vaginosis in women undergoing in vitro fertilisation for different types of infertility. BJOG 2002;109: $714-717$.

5. Morris M, Nicoll A, Simms I, Wilson J, Catchpole M. Bacterial vaginosis: a public health review. 2001;108(5):439-50.

6. Tolosa JE, Chaithongwongwatthana S, Daly S, Maw WW, Gaitán H, Lumbiganon $\mathrm{P}$ et al. International Infections in Pregnancy (IIP) study: variations in the prevalence of bacterial vaginosis and distribution of morphotypes in vaginal smears among pregnant women. Am J Obstet Gynecol. 2006;195(5):1198- 204.

7. Donders GG, Zodzika J, Rezeberga D. Treatment of bacterial vaginosis: what we have and what we miss. Expert Opin Pharmacother 2014;15:645 -657 .

8. Romanik M, Nowosielski $\mathrm{K}$, Poreba $\mathrm{R}$, et al. Streptococcus group B serotype distribution in anovaginal isolates of women in term pregnancy. Neuro Endocrinol Lett. 2014;35:301 $\square 305$.

9. Li YP, Kuok CM, Lin SY, et al. Group B Streptococcus antimicrobial resistance in neonates born to group B Streptococcus-colonized mothers: 
single-centersurvey. J Obstet Gynaecol Res. 2016;42:1471-1475.

10. Hay PE, Lamont RF, Taylor-Robinson D, Morgan $\mathrm{DJ}$, Ison $\mathrm{C}$, Pearson J. Abnormal bacterial colonisation of the genital tract and subsequent preterm delivery and late miscarriage. BMJ 1994;308:295- 298.

11. Rocchetti TT, Marconi C, Rall VLM, Borges VTM, Corrente JE, Da Silva MG. Group B streptococci colonization in pregnant women: risk factors and evaluation of the vaginal flora. Arch Gynecol Obstet 2011;283:717-721.

12. Tavo V. Prevalence of Mycoplasma hominis and Ureaplazma urealyticum among women of reproductive age in Albania. Med Arch 2013;67:25.

13. McCormick T; Ashe RG; Kearny PM. Urinary Tract Infections in pregnancy.Obstetrician and Gynaecologist 2008;10: 156-162.

14. Sevi G., Nick W., Kate C., Gary E., Sarah E.M, and Andrew W. The role of infection in miscarriage. Human Reproduction Update. 2016; 22(1):116133.

15. Vandepitte, J; Verhaegen, J; Engbaek, K; Rohnor, P. Piot, P; Heuk, C C(2003). Basic Laboratory Procedures in Clinical Bacteriology, 2nd edition. WHO. Geneva. pp32 - 35.

16. Bauer, A. W., W. M. M. Kirby, J. C. Sherris, and M. Turck. 1966. Antibiotic susceptibility testing by a standardized disk method. Am. J. Clin. Pathol. 45:493-496.

17. Suzumori N, Sugiura-OgasawaraM. Genetic factors as a cause of miscarriage. Curr Med Chem 2010;17:3431-3437.

18. Allanson B, Jennings B, Jacques A, Charles AK, Keil AD, Dickinson JE. Infection and fetal loss in the mid-second trimester of pregnancy. Aust N Z J Obstet Gynaecol 2010; 50:221-225.

19. Anatolijs N. andElvīra T. The most common isolated microorganisms and its clinical manifestation in hospitalised women suffering from urogenital diseases in Latvia. Naumčiks A et al. Int J Reprod Contracept Obstet Gynecol. 2015;4(4):959-962.

20. Montero Alonso R, Barbadillo Izquierdo F, Ansó Oliván S, Marrero Calvo M, Carpintero Martín I, Sastre Huerta E et al. [Neonatal sepsis caused by Streptococcus agalactiae. What should be done?]. An Esp Pediatr. 1998;48(3):288-92.
21. Zhiyao C., Guoming W., Xuelian C., Shunming L., Xiaolin W., Zhenjiang Y., Chuan'an W. and Xiaohua Y. Group B streptococcus colonisation and associated risk factors among pregnant women: A hospital based study and implications for primary care. Int J Clin Pract. 2019;73:e13276.

22. Colbourn T, Gilbert R. An overview of the natural history of early onset group B streptococcal disease in the UK. Early Hum Dev. 2007;83:149-156.

23. Li YP, Kuok CM, Lin SY, et al. Group B Streptococcus antimicrobial resistance in neonates born to group B Streptococcus-colonized mothers: single-centersurvey. J Obstet Gynaecol Res. 2016;42:1471-1475.

24. Xin T., Shu-qi G., Lei C., Li-si C., Muh-fa H., and Chiung-lang W. Relationships between female infertility and female genital infections and pelvic inflammatory disease: a population-based nested controlled study. CLINICS 2018;73:e364: 1-6.

25. Al-Badr A, Al-Shaikh G. Recurrent urinary tract infections management I women: A review. Sultan Qaboos Univ. Med. J. 2013; 13: 359-367.

26. Giovanni N., Manuela M., Elisabetta M., Gian C., Gaspare C. and Maurizio M. Role of the infections in recurrent spontaneous abortion. The Journal of Maternal-Fetal and Neonatal Medicine, 2011; 1-7.

27. Hay PE, Lamont RF, Taylor-Robinson D, Morgan DJ, Ison C, Pearson J. Abnormal bacterial colonisation of the genital tract and subsequent preterm delivery and late miscarriage. BMJ 1994;308: 295-298.

28. Oakeshott P, Hay P, Hay S, Steinke F, Rink E, Kerry S. Association between bacterial vaginosis or chlamydial infection and miscarriage before 16 weeks' gestation: prospective community based cohort study. BMJ 2002;325:1334-1338

29. Ranganathan V. Urinary tract infection: an overview of the infection and the associated risk factors. J Microbiol Exp. 2014;1(2):42-54.

30. Inmaculada M., Ettore Cicinelli, M., Iolanda Garcia-G., Marta Gonzalez-M., Davide B.,Felipe V., Dominique D., Leonardo R., Diana Valbuena, M. and Carlos Simon, M. The diagnosis of chronic endometritis in infertile asymptomatic women: a comparative study of histology, microbial cultures, hysteroscopy, and molecular microbiology. Am J Obstet Gynecol 2018;218:602.e1-16. 
31. Cicinelli E, Matteo $\mathrm{M}$, Tinelli $\mathrm{R}$, et al. Prevalenceof chronic endometritis in repeated unexplainedimplantation failure and the IVF successrate after antibiotic therapy. Hum Reprod. 2015;30:323-30.

32. Apostolos K., Stefania P., and George M. Septic shock due to Klebsiellapneumoniae after medical abortion with misoprostol-only regimen. Fertility and Sterility.2010; 94(4): 1529.e2-5.

33. Okoroiwu .G. and Wachukwu C. Studies on the Role of Escherichia coli in Pregnancy Related Miscarriages (Spontaneous Abortions) In Upland Area of Rivers State of Nigeria.Am. J. PharmTech Res. 2015; 5(6): 386-394.
34. Donders G., Moerman P., Caudron J. and Van Assche F. Intra-uterine Candida infection: a report of from two mothers four infected fetuses. European Journal of Obstetrics \& Gynecology and Reproductive Biology. 1990 (38): 233-238.

35. Wondemagegn M., Mulat Y., Yohannes Z., and Bayeh A. Common causes of vaginal infections and antibiotic susceptibility of aerobic bacterial isolates in women of reproductive age attending at Felegehiwot referral Hospital, Ethiopia: a cross sectional study. BMC Women's Health. 2015; 15:42: 1-9. 